Article

\title{
Diversity Bears Fruit: Evaluating the Economic Potential of Undervalued Fruits for an Agroecological Restoration Approach in the Peruvian Amazon
}

\author{
Elisabeth Lagneaux 1,2,3,4,*(D), Merel Jansen 5,6,7,8,9,*(D), Julia Quaedvlieg ${ }^{5,6,10}$, Pieter A. Zuidema ${ }^{3}$ (D), \\ Niels P. R. Anten ${ }^{4}$, Mishari Rolando García Roca ${ }^{11}$, Ronald Corvera-Gomringer ${ }^{12} \mathbb{D}$ and Chris J. Kettle ${ }^{5,13, * \mathbb{D}}$
}

check for updates

Citation: Lagneaux, E.; Jansen, M.; Quaedvlieg, J.; Zuidema, P.A.; Anten, N.P.R.; García Roca, M.R.;

Corvera-Gomringer, R.; Kettle, C.J. Diversity Bears Fruit: Evaluating the Economic Potential of Undervalued Fruits for an Agroecological Restoration Approach in the Peruvian Amazon. Sustainability 2021, 13, 4582. https://doi.org/10.3390/su13084582

Academic Editor: Filipa Monteiro

Received: 31 March 2021

Accepted: 14 April 2021

Published: 20 April 2021

Publisher's Note: MDPI stays neutral with regard to jurisdictional claims in published maps and institutional affiliations.

Copyright: (c) 2021 by the authors. Licensee MDPI, Basel, Switzerland. This article is an open access article distributed under the terms and conditions of the Creative Commons Attribution (CC BY) license (https:// creativecommons.org/licenses/by/ $4.0 /)$.
1 Plant Production Systems Group, Wageningen University, 6708 PB Wageningen, The Netherlands

2 Group of Environmental Economics, Institute for Environmental Sciences, University of Koblenz-Landau, 76829 Landau, Germany

3 Forest Ecology and Forest Management Group, Wageningen University, 6708 PB Wageningen, The Netherlands; pieter.zuidema@wur.nl

4 Centre for Crop Systems Analysis, Wageningen University, 6708 PB Wageningen, The Netherlands; niels.anten@wur.nl

5 Department of Environmental Systems Science, Ecosystem Management, USYS, ETH Zürich, 8092 Zurich, Switzerland; juliaquaedvlieg@gmail.com

6 Center for International Forestry Research (CIFOR), 15024 Lima, Peru

7 Institute for Environmental Sciences, Geoecology \& Physical Geography, University of Koblenz-Landau, 76829 Landau, Germany

8 Center for Environmental Systems Research, Kassel University, 34117 Kassel, Germany

9 Institute of Geography, University of Hamburg, 20146 Hamburg, Germany

10 International Institute of Social Studies (ISS), Erasmus University Rotterdam, Kortenaerkade 12, 2518 AX The Hague, The Netherlands

11 Facultad de Ingeniería Forestal y Medio Ambiente, Universidad Nacional Amazónica de Madre de Dios (UNAMAD), 17001 Puerto Maldonado, Peru; madreselva.consultores@gmail.com

12 Instituto de Inverstigación de la Amazonia Peruana (IIAP), 17001 Puerto Maldonado, Peru; rcorvera@iiap.gob.pe

13 Bioversity International, Via di San Domenico, 100153 Rome, Italy

* Correspondence: elisabeth.lagneaux@wur.nl (E.L.); merel.jansen@uni-landau.de (M.J.); chris.kettle@env.ethz.ch (C.J.K.)

Abstract: Agroforestry systems with a range of native and often neglected and underutilized tree species (NUS) are increasingly recognized for their potential role in restoration, simultaneously providing ecological and livelihood benefits. Successful adoption of these systems requires knowledge about beneficial species, system-level potential profitability, and barriers faced by farmers. Such information is essential but lacking for most NUS. We analyzed the economic potential of NUS in diverse smallholder-managed agroforestry systems in the Peruvian Amazon. Through semistructured surveys with local stakeholders $(n=40)$, we identified 10 native Amazonian NUS fruit with ecological, nutritious and commercial benefits. We then simulated the potential revenue per species and system-level profit of an agroforestry system designed with the 10 NUS. Our projections suggest that a diverse NUS-based agroforestry system can outcompete most alternative land-uses in the region on a per hectare profit basis. This shows that including NUS in restoration efforts could provide economic benefits for smallholders. To realize this potential, we recommend adapted interventions, e.g., increased farmer access to planting material, technical support for production and capacity building with a focus on high-potential NUS.

Keywords: agroecology; forest landscape restoration; agroforestry; diversity; neglected and underutilized fruit; profit; revenue; Peruvian Amazon 


\section{Introduction}

Globally awareness is growing regarding the need to restore lands degraded by decades of large-scale deforestation [1]. Forest landscape restoration aims to simultaneously enhance ecological functioning, ecosystem service delivery and human wellbeing in degraded forest landscapes [2]. Agroecological approaches in general, and agroforestry in particular, are increasingly seen as essential tools for restoration interventions since they can provide a variety of ecosystem services while simultaneously contributing to food security and livelihood improvement [3-8]. In the IUCN guide to the Restoration Opportunities Assessment Methodology (ROAM) [9], the term 'agroforestry' is mentioned 48 times, showing that forest landscape restoration and agroforestry are increasingly considered complementary to each other.

To maximize the multiple benefits of agroforestry systems within agroecological restoration approaches, agroforestry systems should be diverse and largely based on native species $[10,11]$. The commercial potential of tropical non-wood products such as fruits has been known for decades [12]. Currently, in the Americas alone, 1257 fruits are registered in the New World Fruit database [13], many of which have the potential to be included in diverse agroforestry systems. Despite their multiple benefits, many of these species are currently neglected or underutilized (NUS) [14]. NUS have been defined as crops that hold significant potential for improving diets and nutrition, while protecting agrobiodiversity, but that are marginalized [15]. Under the pressure of international market forces, diverse agroforestry systems that include NUS have often been replaced by agroforestry systems based on just one or two cash crops (e.g., [16,17]), which strongly limits both the environmental and livelihood benefits these systems provide [10].

The successful implementation of diverse NUS-based agroforestry systems in agroecological restoration interventions is not straightforward. It relies on pre-requisite knowledge, related to the local socio-economic reality [18]. First, the choice of NUS must be based on locally grown species with known nutritional benefits. Identifying species with additional commercial and ecological benefits will increase the chances to meet restoration objectives [19]. Yet, while many studies have evaluated single benefits (e.g., [20,21]), very few have evaluated multiple benefits simultaneously. Second, the economic viability of the NUS-based agroforestry system must be estimated. Recent studies have evaluated economic viability of diverse agroforestry systems [22,23]. However, the systems evaluated in these studies were mostly based on well-known cash crops such as corn, banana, cacao, citrus and cassava, and therefore do not provide information on the economic potential of including NUS in agroecological restoration approaches. ROAM guidelines provide a useful framework to simply evaluate costs and benefit of restoration interventions, based on local stakeholder-reported values [9]. A third key factor for restorative success is understanding the barriers to farmer's adoption of NUS in agroforestry systems [14]. However, in the case of NUS-based restoration approaches, the motivations for adoption are complex and still poorly understood.

In this study we analyze the economic potential of NUS within diverse smallholdermanaged agroforestry systems, for agroecological restoration approaches. Specifically, we (1) identify 10 underutilized native Amazonian fruit species which have, in the perception of farmers and agroforestry specialists, high potential in terms of ecological, nutritional and commercial benefits, (2) estimate the potential revenue over time of individual trees of these species, (3) estimate the potential costs and revenues over time of an agroforestry system designed with the previously identified species, based on local farmers preferences, and (4) explore barriers to adoption by identifying the main reasons mentioned by local farmers for planting or not planting those high-potential species.

We combine the use of ROAM with data from structured and semi-structured surveys and field observations made in the south-eastern Amazon, in the Peruvian department of Madre de Dios. 


\section{Materials and Methods}

\subsection{Study Region}

The department Madre de Dios, in the western part of the Amazon basin, is located in the south-east of Peru. The region is $85,300 \mathrm{~km}^{2}$ in size, almost entirely covered (95\%) by rainforest [24]. 2017 was a year of historically high forest cover loss of over 20,000 hectares, doubling the loss of 2008. For the first time, the region was second in the ranking of Peruvian departments with highest forest cover losses [25] and it remains among the Peruvian departments with highest deforestation rates [26]. Historically colonized by consecutive migration waves, the department is today attracting Andean immigrant populations who are driven by the economic perspectives offered to rural workers in the sectors of informal gold mining and agriculture. These land-uses are the main drivers of the region's high deforestation rates [27] and have benefited from the recent paving of the Inter-oceanic Highway, along which all recent deforestation hotspots are located [25].

Farmers in Madre de Dios are mostly smallholder colonists [28] who manage a wide range of farm systems, ranging from highly diverse agroforests and home gardens to extensive pastures and monocultures. Many of them benefited from rural colonization policies in the 80ies, that provided them with large plots of land (up to 400 hectares) to allow for slash-and-burn cultivation [29]. The largest regional agroforestry development programs happened in the 90ies, for example with the government-led project INRENAITTO that led to the establishment of 1500 ha of agroforestry systems [30]. Today, the land of most farmers includes mature but degraded forest, and it is only cultivated in parts. As agriculture has become the main alternative land use promoted by the local government to transition away from illegal mining, several public programs (e.g., AGROIDEAS [31]) are promoting crop conversions to shift from regionally marketed foods towards commodity cash crops. The cultivated surface of cacao, for example, has doubled between 2010 and 2017 [32]. These interventions on the farming system and the consequential agricultural intensification are likely to affect most local smallholder farmers. While extractive activities such as illegal gold mining or Brazil Nut harvesting have been widely studied in Madre de Dios (e.g., $[33,34]$ ), there have been very few studies on the local farming systems, about interventions that can reconcile crop diversity with livelihoods, and their potential to restore degraded land.

\subsection{Research Framework}

To analyze the economic potential of NUS within diverse smallholder-managed agroforestry systems, we used an adaptation of the framework presented in the ROAM guide [9]. Table 1 shows the ROAM guideline steps for estimating costs and benefits, and the associated method we chose. Our study consisted of the identification of high-potential NUS fruit, the estimation of potential profitability of their production over time (both for individual trees and for a system we designed that combines the identified species) and the exploration of reasons mentioned by local farmers for planting the identified species or not. 
Table 1. The 4 steps in the ROAM framework to estimate costs and benefits of restoration interventions (left column), and the corresponding method used in this study to analyze the economic potential of NUS within diverse smallholder-managed agroforestry systems, for agroecological restoration approaches.

\begin{tabular}{|c|c|c|}
\hline & ROAM Guidelines & This Study's Associated Method \\
\hline 1 & $\begin{array}{l}\text { "Agree on the main restoration interventions being } \\
\text { considered, where and under what conditions." }\end{array}$ & $\begin{array}{l}\text { Restoration intervention based on the implementation of diverse, } \\
\text { fruit and NUS-based agroforestry systems, with smallholder } \\
\text { farmers in Madre de Dios. We identified } 10 \text { high-potential native } \\
\text { NUS fruit based on interviews with agroforestry specialists } \\
(n=11) \text { (objective 1). }\end{array}$ \\
\hline 2 & $\begin{array}{l}\text { "Make a relatively reliable estimate of the different technical } \\
\text { specifications involved in [the] intervention (... ) and the } \\
\text { incremental benefits (or changes) that should be produced" }\end{array}$ & $\begin{array}{c}\text { First, we identified the types of costs associated with the } \\
\text { implementation of agroforestry systems based on literature } \\
\text { [35,36]. Then, we collected this cost data, and productivity and } \\
\text { price data by interviewing farmers }(n=23) \text { and commercial } \\
\text { specialists }(n=7) \text {. Next, we projected each high-potential species' } \\
\text { revenue over } 30 \text { years (objective } 2) \text {. }\end{array}$ \\
\hline 3 & $\begin{array}{c}\text { "Calculate and model the (...) goods and services for } \\
\text { restoration interventions and their associated costs } \\
\text { and benefits." }\end{array}$ & $\begin{array}{l}\text { We projected the potential profit over } 30 \text { years of an agroforestry } \\
\text { system based on the high-potential NUS and designed according } \\
\text { to farmers preference (objective 3). }\end{array}$ \\
\hline & & $\begin{array}{l}\text { We consider both the numerical and social uncertainties of our } \\
\text { analysis by: }\end{array}$ \\
\hline 4 & "Conduct a sensitivity and uncertainty analysis" & $\begin{array}{l}\text { 1. Determining } 95 \% \text { confidence intervals of our agroforest } \\
\text { revenue and profit projections (Section } 2.2 .3 .2) \text {; } \\
\text { 2. Identifying the main reasons mentioned by local farmers for } \\
\text { planting or not planting the species that the model is based } \\
\text { on (objective 4). }\end{array}$ \\
\hline
\end{tabular}

\subsubsection{Data Collection}

To complete each objective of the study, we relied on one literature review and interviews with three groups of local stakeholders: agroforestry specialists, commercial specialists and farmers.

The literature review was aimed at identifying Amazonian tree-sourced foods and medicinal non-timber forest products (NTFPs) in the region of Madre de Dios. We searched for scientific literature containing the keywords "ethnobotany", "home-gardens", "NTFPs", "agroforestry" and "analog forestry" combined with "Madre de Dios" or "Amazonian Peru" on the search engine Google Scholar. In total, 21 species were selected based on the following criteria: (1) the species is a NUS, meaning that they are economically viable and nutrient-rich, but marginalized by researchers, breeders and policy-makers [37]; (2) there is evidence of commercial trading in Peru or abroad; (3) the species is native to the Amazon and adapted to the specific climatic and soil characteristics of Madre de Dios; (4) the species has either an edible and/or medicinal function. The 21 species that resulted from this literature review are listed in Table S1 (see Supplementary Materials).

Then, we identified and interviewed 11 local agroforestry specialists from governmental and non-governmental institutions in order to determine which of the 21 identified species provide most ecological, nutritional, and commercial benefits. Five of these specialists were identified by means of a Google search of local agroforestry NGOs. The other six specialists were identified based on the first interviewees' recommendations. Table S2 (see Supplementary Materials) lists the institutions related to each agroforestry specialist. The questionnaire for the interview was designed to evaluate the three benefits: ecological, nutritional and commercial, each related to two criteria. The six criteria were tested in a set of 10 structured questions with yes/no answers. The criteria for ecological benefits were growing conditions (tolerance to drought and degraded soils) and ecosystem services (positive effect on the soil). The criteria for nutritional benefits were the perceived nutritional and medicinal benefits and the potential for local diet diversification. The criteria 
for commercial benefit were the current market value and the perceived market potential (Table S3 of the Supplementary Materials).

Finally, semi-structured interviews were carried out with 23 farmers and 7 commercial specialists to gather information on farm characteristics, the productivity and prices of the identified high-potential NUS and the monetary costs associated with the establishment and management of an agroforestry system. A list of potential costs to include was adapted from Torres et al. (2010) [36] and Cardozo et al. (2015) [35].

The farmers we interviewed were selected using snowball sampling [38]. The starting point of the selection were contacts recommended by the Asociación Agricultura Ecológica (AAE), a local farmers association, and based on the condition that farmers considered themselves to practice agroforestry. The resulting sampled farmers where mainly men (over 90\%), owning in average around 40 ha of land and with almost 20 years of farming experience. Most (55\%) were first or second generation of migrants from the Andes. In total, there are 150 agroforestry farms with over four years of implementation in the province of Tambopata [39], the largest and by far most populous of the three provinces in Madre de Dios. Based upon the above we estimate that we sampled about $15 \%$ of the farmers in this province.

The commercial specialists (only one overlapping with agroforestry specialists interviewed, see Table S2 in Supplementary Materials) were selected to represent a diversity of sectors: academic, private, producer association and NGO.

To design a system representative of the region's agroforestry systems, we asked farmers about the size of their farm and the number of species they managed, and based cropping density and structure on field observations (during visits of the interviewees farm) and interviews with farmers and a commercial specialist. Further, to determine potential monetary income that can be obtained with the production of the identified NUS, we asked both farmers and commercial specialists about the first year of harvest, months of production per year, productivity per tree (yields), and price per unit on the local market for the NUS they had experience with (see questionnaires in Table S4a,b, Supplementary Materials). We selected one commercial (from the NGO Camino Verde) for his expertise on agroforestry system implementation and interviewed him more extensively to obtain information regarding increases in production over time after the start of production for each of the high-potential NUS. To determine total monetary costs, we collected information about seedling costs, replacement rates throughout time, local salaries (to determine farm installation costs and costs for maintenance and harvest operations), costs of transportation to the market and losses due to unsold products among the commercial specialist that was interviewed more extensively and two farmers who were interviewed in a later round of interviews, in one case during the weekly food fair in Puerto Maldonado (to gather data on food loss), and in the other case on-farm (to gather data on transportation costs) (see Table S5 in the Supplementary Materials for an overview of the different data sources).

During the interviews with farmers, we also asked about their motivation to grow each of the high-potential species or not. Farmers were shown a list with the 10 high-potential NUS and asked structured questions about each, such as whether they currently grew it or not, and why.

Figure 1 shows the flow of data associated to each specific objective and interview. 


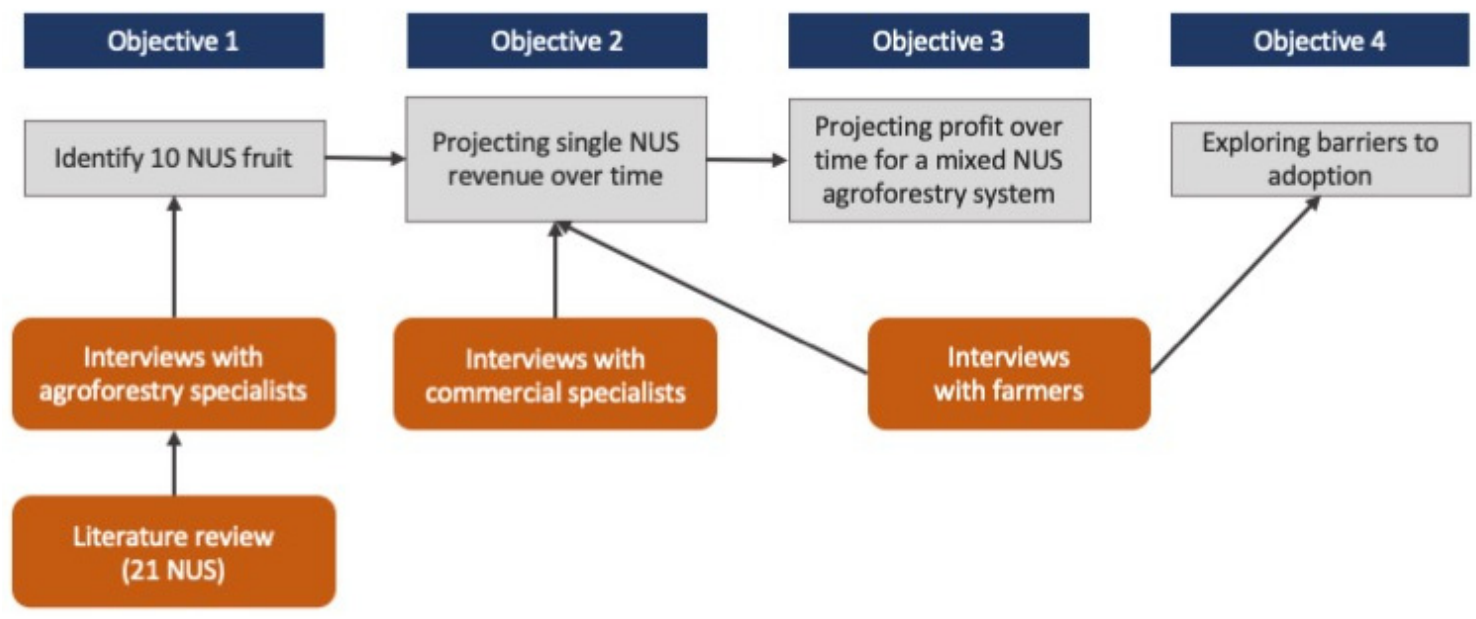

Figure 1. Flow of data between the four specific objectives of this study and the literature review and three sets of interviews with $n=40$ local stakeholders.

\subsubsection{Identifying High-Potential NUS Fruit}

We averaged the amount of "yes" answers from the agroforestry specialist interviews for each benefit in order to provide a total score per benefit. Then, the 10 species with highest overall benefit scores were selected for the following steps of the study and will be referred to as high-potential species. By taking the total score into account, both species with high scores on one type of benefit and species which scored well for multiple benefits could be selected, allowing for the different species to complement each other in a combined system.

\subsubsection{Estimating the Profitability of NUS Production}

\subsubsection{Projecting Single Species Revenue over Time}

Based on the collected data, we projected potential revenue over a time period of 30 years for individual trees of each of the high-potential NUS and estimated uncertainty in these estimations. A period of 30 years was chosen because it would allow all high-potential species to reach maturity. To be able to make the projections, we first, for each of the NUS, estimated annual yield of a producing tree by averaging the yield values reported in the interviews. Then, we estimated average market price (per unit) similarly. In most cases, instead of giving one value, farmers gave a maximum and minimum value based on yearly price fluctuation. In those cases, we averaged both values. We made similar calculations to determine the number of years until first production (again by averaging values reported by the interviewees). The resulting values are provided in Table S6 of the Supplementary Material. Further, based on recommendations of one of the interviewees, we assumed that from the year in which a tree is first reproductive, production gradually increases over a period of 3 years until full production (i.e., the average of the production values reported by the interviewees) is reached. An exception was the short-term crop cocona (Solanum sessiliflorum) for which we assumed full production was reached in year 2 of production. In addition, based on recommendations of the same interviewee, we assumed that the production of cocona decreases with the same speed as it increased (resulting in 3 productive years in total), and that the production of arazá (Eugenia stipitat) is $75 \%$ of full production in the 5 th year of production and $50 \%$ of full production from the 6th year onwards. Based on these calculations and assumptions, we projected average production of each selected species over 30 years. We then calculated total production over 30 years by summing the values of individual years. To estimate uncertainty in our projections, we used bootstrap sampling $(n=10,000)$ and calculated $95 \%$ confidence intervals for each projected year. Bootstrap sampling was performed per species from the productivity, time until production and price values provided by the interviewees. All analyses were 
performed in RStudio [40,41], and the bootstrapping with the boot function of the boot package for R [42]. R-script of these projections is provided as Supplementary Material.

\subsubsection{Projecting Profit over Time for a Mixed NUS Agroforestry System}

To be able to project potential profit over time of a mixed agroforestry system based on high-potential NUS, we first designed a system with the 10 identified NUS. We based our design on farm characteristics (size, number of species and cropping density and structure) obtained during interviews with the farmers. This allowed us to set the following criteria:

1. The total size of the system is 4 ha. This is less than the 7.4 ha in average that the farmers we interviewed indicated they dedicate to agroforestry on their land. However, we chose for a slightly smaller design in our projections because 4 ha is considered the maximum manageable size for a single farmer to implement over one year (Camino Verde, pers. comm. July 2018) and we considered farmers to be able to sell all their produce at the local market, without the intervention of a broker.

2. Trees are planted in rows, with a distance of $5 \mathrm{~m}$ between individual trees resulting in a $5 \times 5 \mathrm{~m}$ surface per tree (which corresponds to the crop density observed on farmer's fields during interviews), except for cocona, which was planted with 2 plants per $5 \times 5 \mathrm{~m}$ surface due to its small size and as per recommendation of one of the interviewees.

3. Half of the rows within the agroforestry system are composed of light demanding species, i.e., camu-camu (Myrciaria dubia) and guanabana (Annona muricata) and the short-term producer cocona. The other half of rows is composed of shade givers, i.e., all palms and guaba (Inga edulis) and shade-tolerant species, i.e., arazá and copoazu (Theobroma grandiflorum). The division of species based on their ecological characteristics was also recommended by one of the interviewees.

The resulting design is illustrated in Figure 2, along with the number of plants per species per 4 hectares and their category.

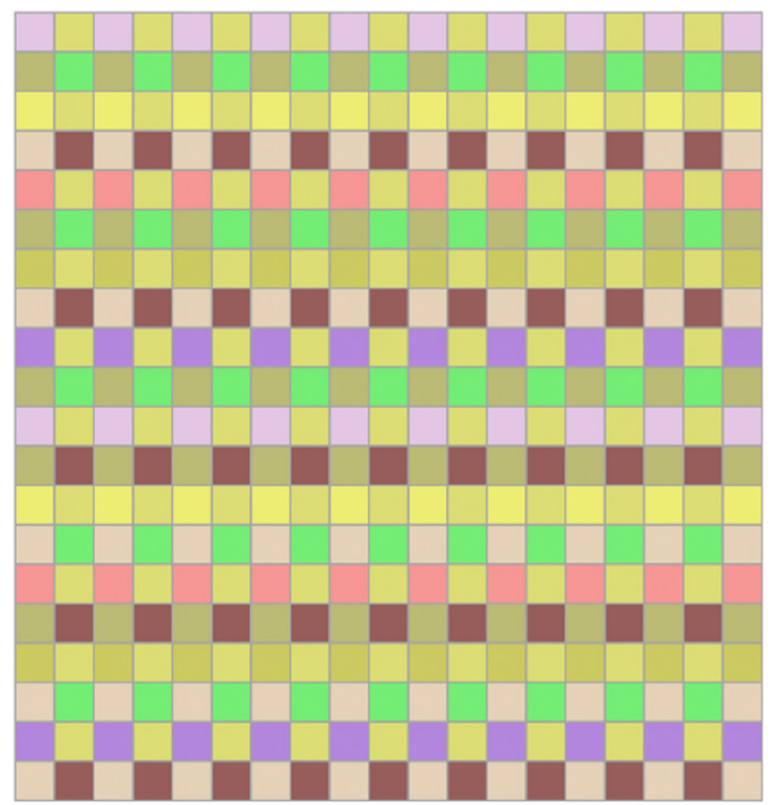

\begin{tabular}{|c|c|}
\hline Legend & Number of plants per 4 ha \\
\hline \multicolumn{2}{|l|}{ Shade-giver } \\
\hline Huasai (Euterpe precatoria) & 80 \\
\hline Aguaje (Mauritia flexuosa) & 80 \\
\hline Guaba (Inga edulis ) & 80 \\
\hline Pijuayo (Bactris gasipaes) & 80 \\
\hline Ungurahui (Oenocarpus bataua) & 80 \\
\hline \multicolumn{2}{|l|}{ Shade-tolerant } \\
\hline Araza (Eugenia stipitata) & 200 \\
\hline Copoazu (Theobroma grandifforum) & 200 \\
\hline \multicolumn{2}{|l|}{ Light-demanding } \\
\hline Guanabana (Annona muricata) & 200 \\
\hline Camu-camu (Myrciaria dubia) & 200 \\
\hline \multicolumn{2}{|l|}{ Short-term } \\
\hline Cocona (Solanum sessiliflorum) (2 per square) & 800 \\
\hline
\end{tabular}

Figure 2. Representation of one hectare of the mixed NUS agroforestry system design based on the 10 identified highpotential NUS, along with the number of plants per species per 4 hectares and their category. Each square represents a $5 \times 5 \mathrm{~m}$ surface. Half the rows are composed of light-demanding and short-term producers, and half the rows are composed of shade givers and shade-tolerant species.

To project potential revenue, costs and profit of the designed system over a period of 30 years, we performed similar calculations and projections as for the individual species 
(Section 2.2.3.1) but multiplied the estimations by the number of species in the system and added estimations of the costs associated with the implementation and management of an agroforestry system (the information for this was obtained by means of interviews, see Section 2.2.1). Costs in each of the projected years were calculated as follows: in the first year (year of installation), costs included hiring help for preparing the land for planting (i.e., 10,000 PEN for 4 ha) and buying of seedlings (3 PEN per seedling, except for cocona for which seeds can be easily obtained from fruits). A seedling replacement rate was assumed of $15 \%$ in year 2 , of $5 \%$ in year 3, and $0.5 \%$ in other years. In addition, costs for hiring help were calculated 4 days per month per fruit for each month of its fruiting season, at a rate of $50 \mathrm{PEN}$ per day. Based on the interviews, we also determined transportation costs (for transport of products by road) to be 200 PEN per month in each year. We included a 10\% loss from lost or unsold products. Profit was calculated for each year by subtracting the corresponding costs from the revenue. To estimate uncertainty in our projections, we used, as for the single species projections, bootstrap sampling $(n=10,000)$ and calculated $95 \%$ confidence intervals for revenue and costs in each projected year. Bootstrap sampling for revenue was performed over the total productivity, time until production and price data dataset, including all species. For bootstrapping of cost estimations, sampling was performed only over the first year of production data, as the other cost related variables were based on the values provided by one specialist and did therefore not have variation. Temporal variation in production, costs and prices (e.g., due to fluctuating climatic conditions and/or changes in demand) were not included in our projections, since not all interviewees gave price and production ranges. We did however explore the influence of dividing the available space within each category between different species, by performing an additional analysis in which the number of trees of each species in a category was randomized, while maintaining the total number of trees in the category constant (e.g., within the "shade-givers" category each species could vary between 0 and 400 trees, but the total number of trees in this category was always 400). As for the single species analysis, all analysis were performed in RStudio [40,41], and the bootstrapping with the boot function of the boot package for R [42]. R-script of both projections is provided as Supplementary Material.

\section{Results}

\subsection{High-Potential NUS}

We found the 10 species to have the highest overall score regarding ecological, commercial, and nutritional benefits to be, ranked in descending order: copoazu (Theobroma grandiflorum), aguaje (Mauricia flexuosa), huasai (Euterpe precatoria), cocona (Solanum sessiliflorum), guanabana (Annona muricata), guaba (Inga edulis), pijuayo (Bactris gasipaes), camu-camu (Myrciaria dubia), arazá (Eugenia stipitata) and ungurahui (Oenocarpus bataua) (Figure 3).

The species were appreciated by the specialists we interviewed mainly for their commercial benefits, with 13 species receiving over $75 \%$ of positive responses. Copoazu, aguaje and camu-camu ranked highest for commercial benefits (i.e., all specialists that we interviewed indicated these species provide commercial benefits), while not all but still $75 \%$ of specialists indicated the commercial benefits of lucuma (Pouteria macrophylla), caimito (Pouteria caimito), guanabana, ungurahui, pijuayo, cocona, huasai, sangre de drago (Croton dracanoides), copaiba (Copaifera officinalis) and arazá. Very few species were indicated to provide ecological benefits, with only one species, guaba, receiving more than $75 \%$ of positive responses $(94 \%)$. Yet, still a majority of specialists indicated that guanabana, pijuayo, sangre de drago, uvilla (Pourouma cecropiifolia), huasai, shebon (Attalea butyracea), shapaja (Attalea phalerata), shihuahuaco (Dipteryx micranta), copoazu and guaba provided ecological benefits. This is mainly due to the species resistance to droughts and degraded soils and, in some cases, to their positive impact on soil quality, for example in the case of fast-growing species that produce a lot of biomass (e.g., sangre de drago), palms that store carbon in the soil or nitrogen-fixing legumes (e.g., shihuahuaco). Regarding nutritional benefits, 7 species 
received over $75 \%$ of positive responses: arazá, huasai, cocona, ungurahui, aguaje, guanabana and camu-camu. Camu-camu ranked highest for nutritional benefits with $88 \%$ of positive responses (Figure 3). This was due to the species being associated with nutritional or medicinal properties (e.g., camu-camu has high vitamin-C level, huasai was mentioned be rich in anti-oxidants) but also to the specie's potential to diversity the local diet. Overall, our selection of 10 high-potential species provided a diverse and complementary set, with both species with high commercial benefit and low ecological benefit (camu-camu) and their opposite (guaba), in addition to species whose benefits were well distributed among the three types (huasai). The scores for each species' ecological, commercial and nutritional benefits are listed in Table S7 (see Supplementary Material).

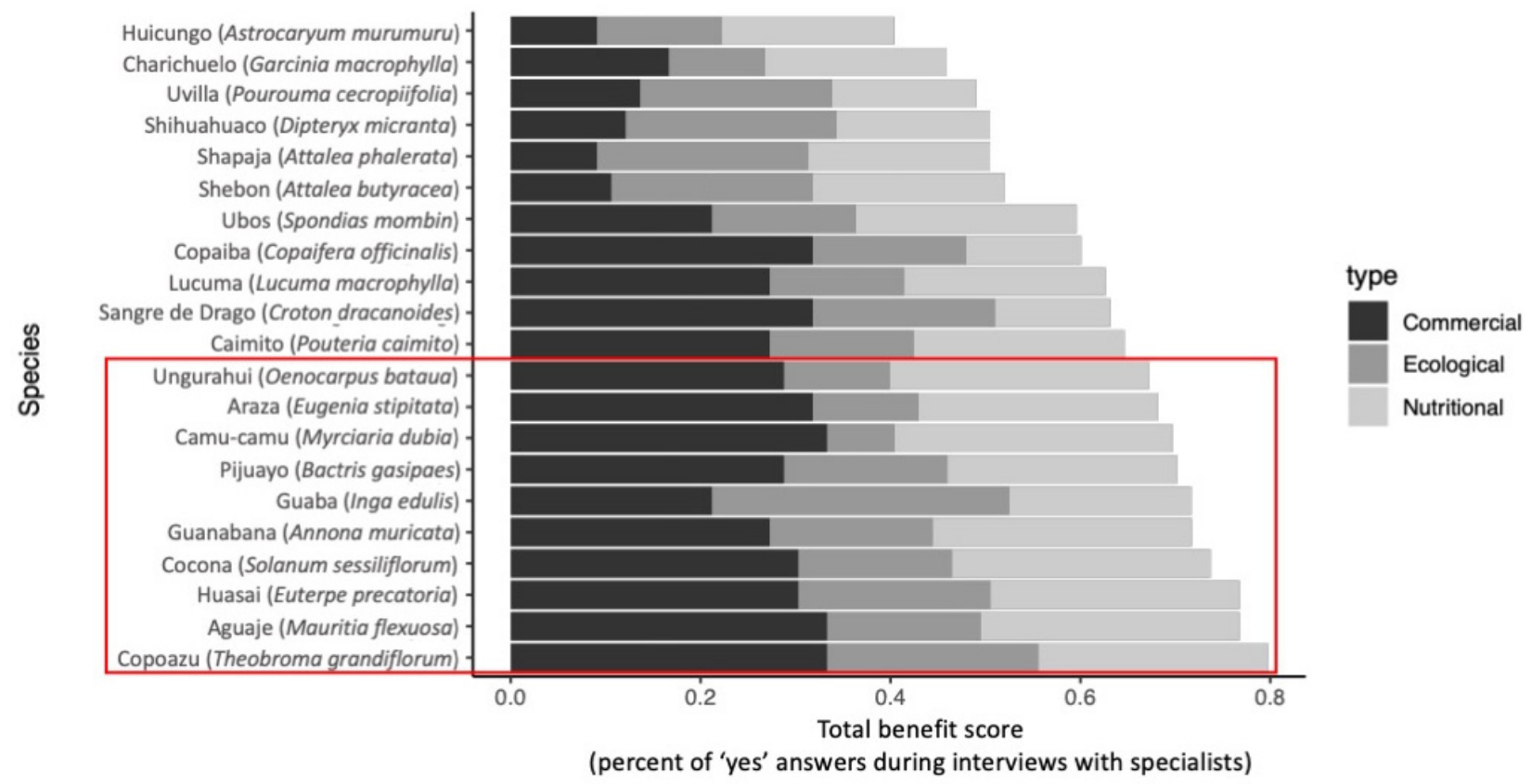

Figure 3. Scores for ecological, commercial and nutritional benefits for different NUS species, based on interviews with agroforestry specialists $(n=11)$ in Madre de Dios, Peruvian Amazon. The 10 species scoring highest (in red) are identified as high-potential species.

\subsection{Potential Revenue of Individual High-Potential NUS}

We found estimated average revenue in local currency (PEN) per NUS over time to vary strongly between species, with highest average revenue after 30 years for camu-camu (345 PEN/y) and lowest for guanabana (12 PEN/y) (Figure 4). The total cumulated revenue over 30 years varies between 8797 PEN for camu-camu and 293 PEN for guanabana (note that discount rates were not taken into account). However, $95 \%$ confidence intervals of revenues, representing the variation in the values that were provided by the interviewees, where large for most species (for revenue after 30 years of camu-camu for example between 39 and 804 PEN, and for guanabana between 7 and 18 PEN, Figure 4). The results indicate that potential revenue likely varies strongly both between and within species. 

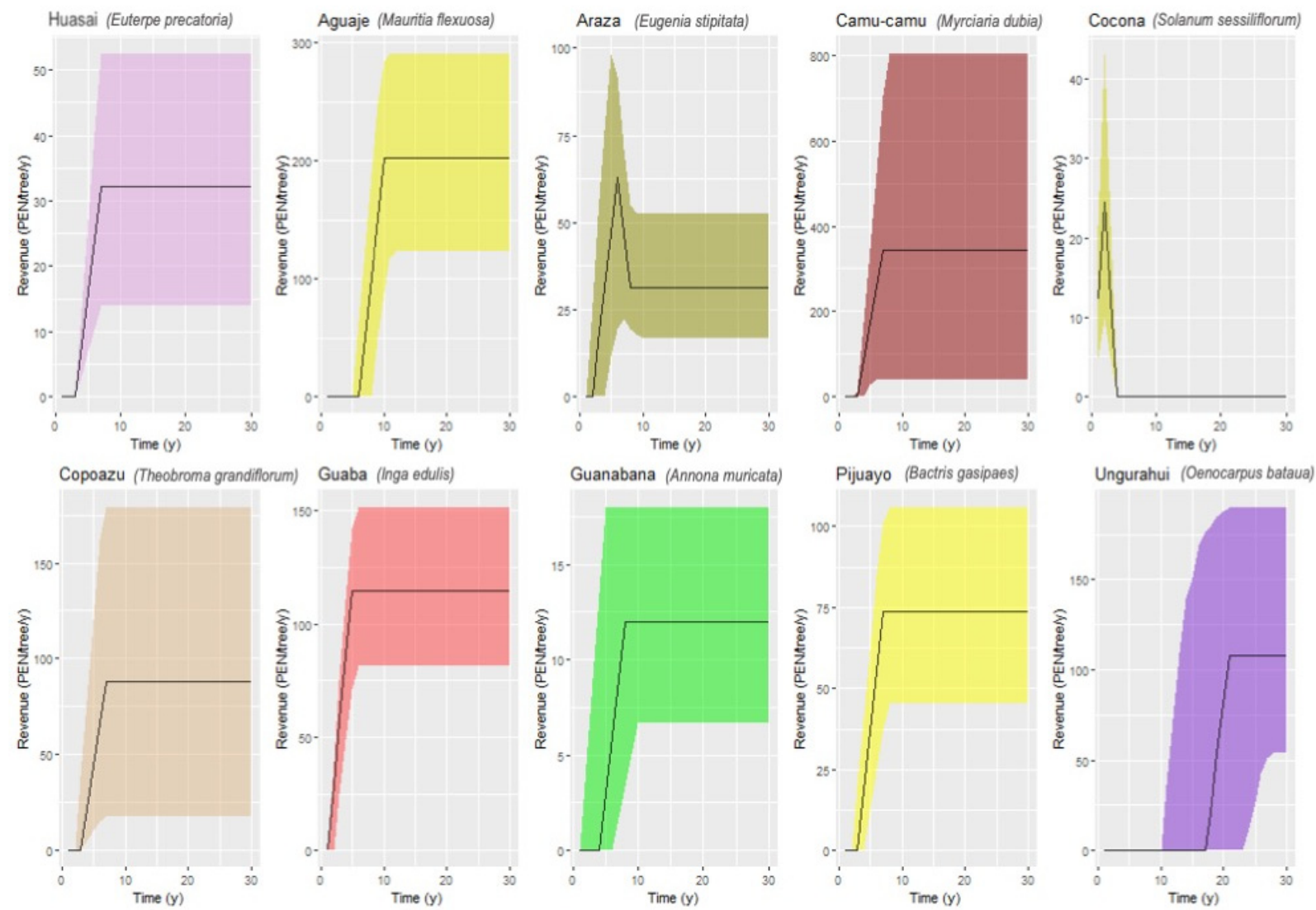

Figure 4. Estimated revenue (PEN/y/tree) of high-potential NUS fruit in Madre de Dios, Peruvian Amazon. Values are based on interviews with farmers $(n=23)$ and commercial specialists $(n=7)$. The colored areas indicate the $95 \%$ bootstrap confidence interval.

\subsection{Potential Profit of a NUS-Based Agroforestry System in Madre de Dios}

Based on our projections, we estimated potential revenue and profit of the agroforestry system we designed based on the 10 identified high potential NUS to be high, with average annual revenue and profit to be 137,846 and 126,228 PEN, respectively after 30 years (Figure 5). Costs were higher than revenues during the first year, after that, revenues exceeded costs (up to a factor 11 from year 7 onwards, Figure 5). The total cumulated profit over 30 years was 3,097,508 PEN (or 1,447,748 PEN when a 5\% discount rate is applied). The confidence intervals of our estimations (which represent the variation in the values that were provided by the interviewees) were large, with $95 \%$ confidence intervals of estimated profit between 58,630 and 243,466 PEN/y from year 28 onwards (Figure 5). When the number of trees of each species within different categories was randomized, average annual profit after 30 years was slightly higher $(134,664$ PEN/y) and confidence intervals were slightly increased, with estimated profit ranging between 47,471 and 311,874 PEN/y from year 28 onwards (Figure S1 of the Supplementary Material). This indicates that the distribution of species within each category has a limited effect on potential profit. Overall, our results suggest that, despite a large uncertainty in total revenue and profit, an agroforestry system based on the 10 high-potential NUS can become profitable within a few years and strongly outweighs initial investment costs after several years. 


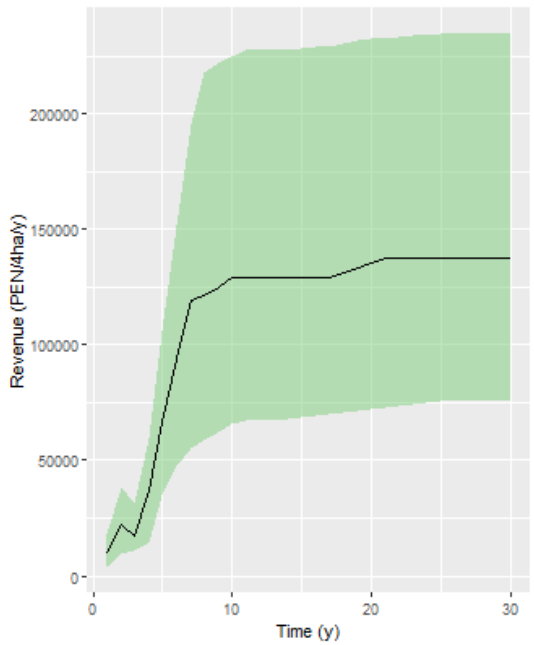

(a)

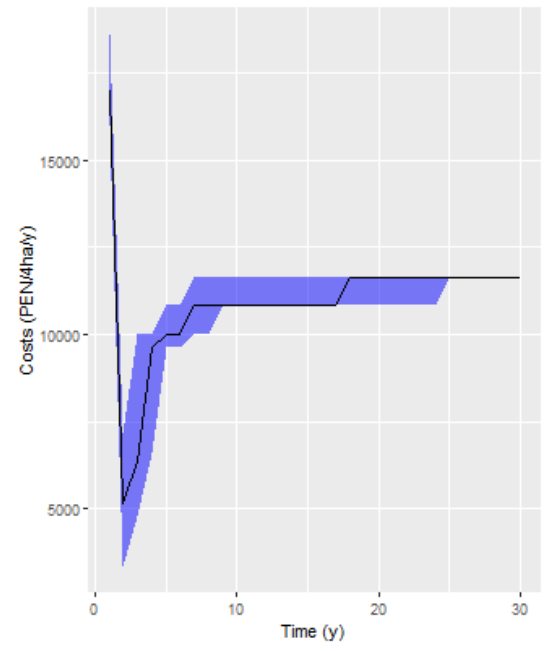

(b)

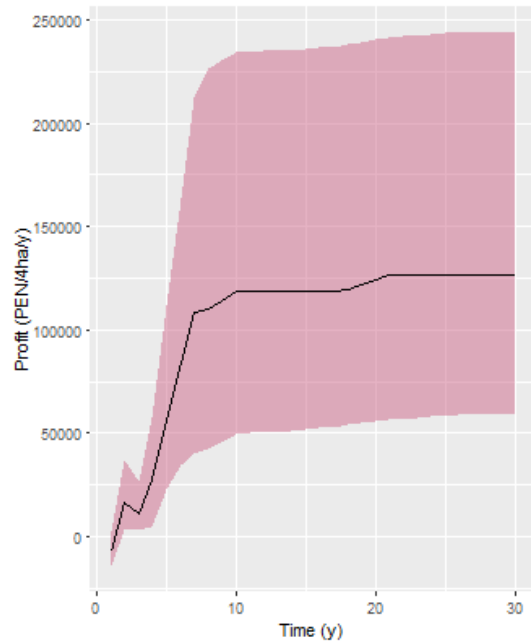

(c)

Figure 5. Projected revenue (a), costs (b) and profit (c) for a diverse agroforestry system based on 10 NUS with high commercial, ecological and nutritional potential as indicated by farmers and specialists in Madre de Dios, Peruvian Amazon. The species that were included in the modelled system were copoazu, guaba, huasai, aguaje, cocona, pijuayo, guanabana, arazá, ungurahui and camu-camu. The colored areas indicate $95 \%$ bootstrap confidence intervals.

\subsection{Reasons Mentioned by Local Farmers for Planting High-Potential NUS or Not}

We classified the motivation mentioned by the farmers we interviewed for planting or not planting each high-potential species into the categories environmental, social, technical and economic.

The main reasons mentioned by the farmers for the cultivation of high-potential species were social $(38.8 \%$ of the reasons mentioned), the main one being the self-consumption of fruits (29.6\%) (Figure 6a). If the consumption for medicinal benefits is added (i.e., the consumption of guanabana leaves, believed by farmers to have anti-cancer properties), the self-consumption rises to more than a third (34.2\% of all reasons mentioned). In total, $28.7 \%$ of the reasons mentioned were environmental, the main one being companion planting to benefit other crops (10.2\%), which was in 9 out of 11 times mentioned for guaba (Inga edulis), a nitrogen-fixing tree used to shade copoazu or cacao plants. Economic reasons represented $26.9 \%$ of all reasons mentioned, the main one being "to sell it" (10.2\%) (Figure 6a).

\section{Reasons mentioned for growing HP species}

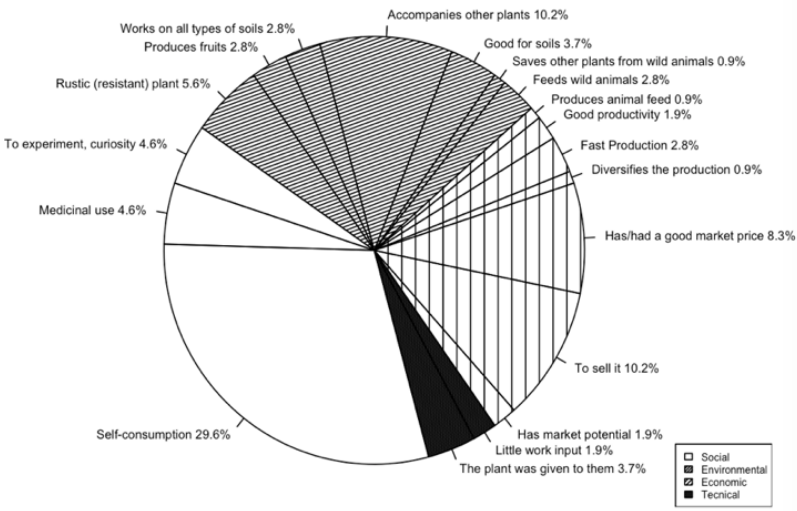

(a)
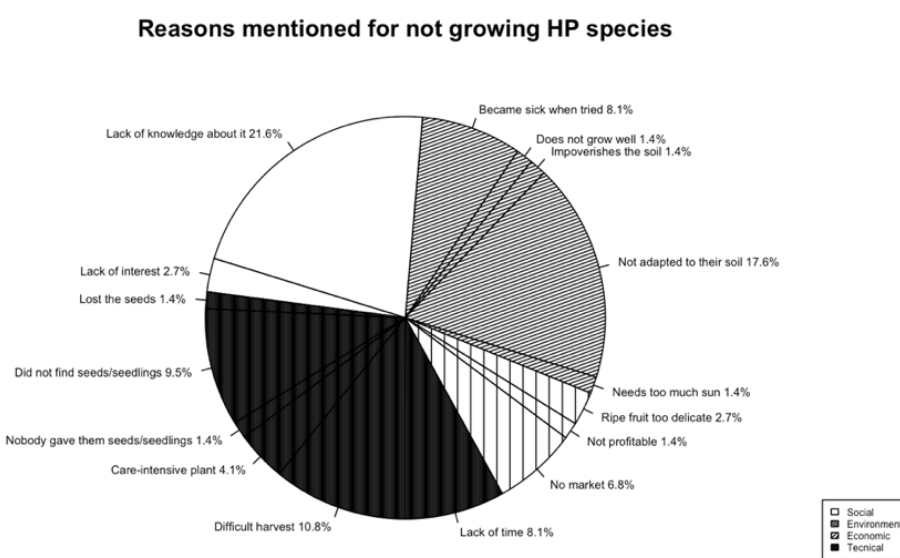

(b)

Figure 6. Reasons mentioned by farmers in Madre de Dios, Peruvian Amazon, to grow the 10 identified high-potential NUS (a) or not to grow them (b). The reasons were categorized as social, environmental, economic and technical. 
Reasons given by farmers for why they do not produce the high-potential species were in majority classified as technical (35.3\% of the reasons mentioned), with difficulty in harvesting $(10.8 \%)$ being the most common reason, which was exclusively related to palm species, where fruit are produced high in the canopy and therefore difficult to reach. Access to seeds and seedlings (i.e not having found any, not being given any, having lost them) represented a total of $12.2 \%$ of all reasons mentioned. Social reasons accounted for $24.3 \%$, with lack of knowledge about the species (21.6\%) being the most common reason. Lack of knowledge was mentioned at least once for each of the high-potential species, except for copoazu and pijuayo. Environmental reasons were $29.9 \%$ of all reasons mentioned, with farmer's belief that the crop is not adapted to his/her land (17.6\%) being the most frequent. Economic reasons were among the least frequent, accounting for $10.8 \%$ of all reasons mentioned, the perception that there is no market for the crop $(6.8 \%)$ being the most common one. This was said three times for arazá, once for pijuayo and once for camu-camu (Figure 6b).

\section{Discussion}

In this study, we identified 10 NUS with high commercial, ecological and nutritional potential in the Peruvian Amazon. Our ROAM framework-based projections of revenue and profit over time of a system in which these 10 species are combined, suggests that diverse NUS-based agroforestry systems can be highly profitable from the second year after implementation. Further, we found the main barriers mentioned by farmers for adoption of NUS species to be knowledge-based and technical. Our study is among the first to identify NUS with highest multiple benefits based on local knowledge and to evaluate their potential profitability within an agroforestry system.

\subsection{Identification of High-Potential NUS}

We identified 10 high-potential NUS for which agroforestry specialists in the Peruvian Amazon indicated that they have a high commercial, ecological and nutritional value. The species status of NUS is confirmed in other studies, which mention them as underutilized [43], "cinderella species" [44,45], undervalued [46] or more recently included them in a list of pantropical NUS fruit [14].

While several studies have already shown some of these species single commercial [47,48], ecological $[20,49]$ and especially nutritious $[21,50,51]$ benefits, very few have looked at multiple benefits simultaneously. To our knowledge, this is the first study to identify NUS with ecological, nutritional and commercial potential, based on local knowledge. By doing so, we provide guidelines about which species to include in forest landscape restoration approaches, emphasizing the restorative potential of agroecological practices.

\subsection{How Much Revenue Can One NUS Fruit Provide?}

We projected that a single species, once productive, provides between 12 and 345 PEN/y of revenue (depending on the species). The confidence interval of these estimations was quite large (e.g., between 39 and 804 PEN for revenue after 30 years of camu-camu). Some of this variation likely reflects production differences due to spatial variation in geophysical factors and/or farmer management practices (see [52]), which can be a challenge when planning restoration activities. However, it is likely that we overestimated the range between which revenue varies, as we did not include covariation over time between prices and production (i.e., when production in a certain year is low, prices are likely higher as supply is low and vice versa) in the confidence interval calculations. Revenue per hectare has previously been estimated for a range of species (e.g., cacao [53], bananas [54,55], coffee [55]). However, these studies mostly focused on cash crops, very few have estimated potential revenue of NUS. Further, to our knowledge, our study is the first to estimate potential revenue per NUS. Knowledge on revenue per NUS can be particularly important for planning of marketing-based funded restoration initiatives (an upcoming funding 
mechanism), as many of such initiatives focus on number of individual trees planted (rather than area planted), and most of such initiatives focus on agroforestry systems [56].

\subsection{Projected Profitability of NUS-Based Agroforestry Systems in Madre de Dios}

We estimated that average profit of the 4 ha system that we designed based on the 10 high-potential NUS, local farm characteristics, and recommendations on ecological requirements, stabilizes after 21 years at an average of 126,228 PEN/year per 4 ha. Our estimations are higher (although still within our estimated 95\% confidence intervals) than those from another study that projected potential profit over time in a diverse agroforestry system in Madre de Dios: Recanati and Guariso (2018) [57], which estimated revenues to reach up to 72,000 PEN/year per 4 ha after 7 years (depending on the number of species that were included). A potential explanation for this difference could be that the Recanati and Guariso (2018) study maximized profit over 15 years using a $0.05 \%$ discount rate, meaning that species that produce sooner are favored in the selection thus potentially excluding "late" earners. We, on the other hand, used a different approach and selected species based on scores provided by interviewees. Interesting though is that both the Recanati and Guariso (2018) study and our study estimate profit of diverse agroforestry system to be much higher than the average income of agroforestry farmers in one of the provinces of Madre de Dios (Tambopata), which was estimated to be around 15,000 PEN/year after about 7 years [39]. Although this can partly be explained due to a poor access to the market for the isolated farmers included in the Peña (2018) report [39], it also suggests that farmer income can be increased if farms are diversified (i.e., farmers in the Peña (2018) study mainly focused on few cash crops with a relatively low market price such as low-quality cacao varieties, citrics and bananas).

In addition, our results (and those of Recanati (2018)) suggest that the implementation of diverse agroforestry systems can be more profitable than alternative current land-uses in Madre de Dios. For example, cattle ranching has been estimated to provide $1008 \mathrm{PEN} /$ year/4 ha of income in Madre de Dios [34,58] (Table 2). This is consistent with the results of studies in other regions of the tropical world that have shown the financial viability of agroforestry compared to other land uses, in particular when focusing on fruit [23] and the financial benefit of using agroforestry as a restoration investment $[22,59,60]$. Yet, some of these studies pointed out the lack of cost-benefit analysis for landscape restoration, especially outside of Africa. Our study helps filling this knowledge gap.

Table 2. Profits generated by land-uses in Madre de Dios, converted to PEN/year/4ha, reported in the literature.

\begin{tabular}{cccccccc}
\hline & $\begin{array}{c}\text { Agroforestry } \\
\text { (Current) }\end{array}$ & $\begin{array}{c}\text { Agroforestry } \\
\text { (Modeled) }\end{array}$ & $\begin{array}{c}\text { Brazil Nut } \\
\text { Extraction }\end{array}$ & Ecotourism & $\begin{array}{c}\text { Cattle } \\
\text { Ranching }\end{array}$ & $\begin{array}{c}\text { Rice } \\
\text { Specialists } \\
\text { Timber } \\
\text { Extraction }\end{array}$ \\
\hline PEN/year & $\begin{array}{c}6000 \text { to } 30,000 \\
(=15,000 \text { in } \\
\text { average })\end{array}$ & 18,000 & 45,084 & & & \\
\hline Hectares & 30 & 1 & 2917 & 2651 & 66 & 40.8 & 4674 \\
\hline PEN/year/4ha & 800 to 4000 & 72,000 & 3.86 & 9258 & 1008 & 406 \\
\hline Source & Peña 2018 & $\begin{array}{c}\text { Recanati and } \\
\text { Guariso, } 2018\end{array}$ & $\begin{array}{c}\text { Garrish et al., } \\
2014\end{array}$ & & Kirkby et al., 2010 [58] \\
\hline
\end{tabular}

We recognize several limitations regarding the approach we used to project potential income over time. First, we did not take into account more complex aspects of pest, disease and climate impacts on production. Although part of this variation was indirectly included in the values that were provided by interviewees, more specific incorporation of this variation would allow for better risk assessment of such impacts. Further, we relied on local knowledge for our estimations, which can be a limitation when people's biases lead to over- or underestimation. However, production data were gathered among farmers, who based their expertise on empirical experience. Despite low levels of formal education, 
farmers had a lot of knowledge about their crop's ecology, production and related income. Comparing the prices per $\mathrm{Kg}$ of fruit reported by farmers with official data about on-farm prices [61] revealed that the prices provided by farmers were only slightly lower, which is consistent with market prices being higher than on-farm prices.

In addition, we assume that market demand always matches farmer's production. However, NUS are mainly produced for local markets, on which their demand can be relatively limited (as was also indicated for several products by the farmers we interviewed). Therefore, if NUS-based diverse agroforestry systems are implemented on large scale, this should go hand in hand with increases in demand, for example by developing new supply chains or through public awareness campaigns that aim to diversify people's diets [10]. Product transformation opportunities (such as drying or making pulps), could help in particular for fruits that are difficult to preserve and transport [14].

\subsection{Why Are Farmers Not Already Adopting NUS-Based Agroforestry Systems and What Would} Enable Them to Do So?

Our analysis provides evidence that four types of limitations influence farmers decisions to cultivate the high-potential NUS: social (lack of knowledge or interest in the species), environmental (mainly due to poor soil conditions), economic (low market or profitability) and technical (mainly due to access to seeds and seedlings and difficult harvest). Interestingly, the technical limitations where much more important than the economic ones, despite what is usually considered regarding limitations to the adoption of crops [62,63]. Yet, technical limitations have also been identified as significant in a study on Latin American NUS fruit trees [14] and in other studies about the adoption of agroforestry [64]. Further, we found the ability to self-consume the fruit, to sell it on the market, or to use it for its environmental services to be the main motivation for farmers to cultivate the NUS. This result is consistent with the results of other studies that showed that farmers prefer fruit trees that are complementary in terms of size and ecology to other crops [65], marketable [14] and that they like to consume [66].

This implies that barriers to the adoption of more high-potential NUS could be lifted with more technical and even financial support to smallholder farmers. Technical support could facilitate the formation of farmers associations and cooperatives, which increases market access and opportunities for product transformation. This is consistent with the conclusions of other studies, which stress the importance of supporting financially viable and culturally embedded agroforestry with supportive, permanent and governmentbacked institutions [59]. In particular, the provision of native seeds and seedlings is key for the upscaling of forest landscape restoration [67].

\subsection{Implications and Directions for Further Research}

Our approach offers clear indications on the species that have a high potential to simultaneously provide multiple benefits, a pragmatic method to explore the potential profitability of NUS based agroforestry over time, and important information on which barriers need to be addressed for the wider adoption of NUS by smallholder farmers. Our analysis therefore contributes to the provision of more informed decisions on the design and implementation of NUS-based agroforestry systems within forest and landscape restoration initiatives, and as such is an important contribution to the debate about agrobiodiversity, forest conservation, landscape restoration and improving rural livelihoods. We believe the next steps for further research aimed at the incorporation of NUS in agroecological restoration initiatives, should focus on the profitability of NUS-based agroforestry systems in a wider range of settings. For example, previous land-use (e.g., grasslands, degraded soils, etc.) might affect costs and productivity. Further, combining NUS with timber, NTFPs (such as Brazil nut, Bertholletia excelsa) and medicinal species can provide higher restorative benefits, especially when canopy trees are included. Non-native species could also be intercropped with native species to provide additional economic value (e.g., pepper) [68].

Our results also have implications at local level. In Madre de Dios, the promotion of agroforestry goes back to the 90ies, when the regional government and several NGOs 
provided farmers with a variety of timber and fruit seedlings [30], some of which were the high-potential NUS identified in this study. Yet, the main species in today's agroforestry systems are timber species, Brazil nut, citrics or copoazu [30]. Most local farmer outreach programs primarily promote only a few species (e.g., cacao, copoazu), risking to erode the local agrobiodiversity rather than to strengthen it [69]. Our results suggest that a different farmer outreach approach, based on the provision of technical support such as access to local high-potential NUS seeds and seedlings, harvesting material and increased capacity building could allow for more diverse smallholder farming systems. These systems have the potential to contribute to the local food systems while providing important means of rural livelihood. The importance of such diversity was demonstrated during the COVID19 crisis both locally, to be able to respond to lack of food supply [70] and globally, as a general measure to reduce impacts of disasters on socioecological systems [71].

Supplementary Materials: The following are available online at https:/ / www.mdpi.com/article/10 $.3390 /$ su13084582/s1.

Author Contributions: Conceptualization, E.L. and M.J.; methodology, E.L., M.J., J.Q.; formal analysis, E.L., M.J.; writing—original draft preparation, E.L., M.J.; writing—review and editing, E.L., M.J., J.Q., P.A.Z., N.P.R.A., M.R.G.R., R.C.-G., C.J.K. All authors have read and agreed to the published version of the manuscript.

Funding: This study was financially supported by the Coop Research Program of the ETH Zurich World Food System and by the Forest Trees and Agroforestry program of the CGIAR. E.L. acknowledges funding of the Stichting Het Kronendak. M.J. additionally acknowledges funding from the Swiss National Science Foundation (P400PB_191055/1).

Institutional Review Board Statement: Not applicable.

Informed Consent Statement: Informed consent was obtained from all subjects involved in the study.

Data Availability Statement: The data present in this study are available in supplementary material.

Acknowledgments: We are very grateful to all the local farmers and other specialists who have shared their time and expert knowledge with us. We also would like to thank Marc Moraine for his support and constructive feedback on earlier versions of this work.

Conflicts of Interest: The authors declare no conflict of interest.

\section{References}

1. Bastin, J.-F.; Finegold, Y.; Garcia, C.; Mollicone, D.; Rezende, M.; Routh, D.; Zohner, C.M.; Crowther, T.W. The Global Tree Restoration Potential. Science 2019, 365, 76-79. [CrossRef] [PubMed]

2. Mansourian, S.; Stanturf, J.A.; Derkyi, M.A.A.; Engel, V.L. Forest Landscape Restoration: Increasing the Positive Impacts of Forest Restoration or Simply the Area under Tree Cover? Quality or Quantity in Forest Landscape Restoration? Restor. Ecol. 2017, 25, 178-183. [CrossRef]

3. Béliveau, A.; Lucotte, M.; Davidson, R.; Paquet, S.; Mertens, F.; Passos, C.J.; Romana, C.A. Reduction of Soil Erosion and Mercury Losses in Agroforestry Systems Compared to Forests and Cultivated Fields in the Brazilian Amazon. J. Environ. Manag. 2017, 203, 522-532. [CrossRef]

4. Perry, J.; Lojka, B.; Quinones Ruiz, L.G.; Van Damme, P.; Houška, J.; Fernandez Cusimamani, E. How Natural Forest Conversion Affects Insect Biodiversity in the Peruvian Amazon: Can Agroforestry Help? Forests 2016, 7, 82. [CrossRef]

5. Schroth, G.; Izac, A.-M.N.; Vasconcelos, H.L.; Gascon, C.; da Fonseca, G.A.B.; Harvey, C.A. Agroforestry and Biodiversity Conservation in Tropical Landscapes; Island Press: Washington, DC, USA, 2004; ISBN 978-1-55963-357-4.

6. Shimizu, M.K.; Kato, O.R.; Figueiredo, R.D.O.; Silva, S. Agriculture without Burning: Restoration of Altered Areas with Chop-and-Mulch Sequential Agroforestry Systems in the Amazon Region. Glob. Adv. Res. J. Agric. Sci. $2014,3,8$.

7. Torquebiau, E.; Rapidel, B.; Jagoret, P.; Harmand, J.-M.; Vaast, P. Addressing Climate Change Concerns in Tropical Agroforestry; EURAF: Nuoro, Italy, 2016.

8. Van Dexter, K.; Visseren-Hamakers, I. Linking forest conservation and food security through agroecology: Insights for forest landscape restoration. In Forest Landscape Restoration; Routledge: London, UK, 2018; pp. 119-136.

9. IUCN; WRI. A Guide to the Restoration Opportunities Assessment Methodology (ROAM): Assessing Forest Landscape Restoration Opportunities at the National or Sub-National Level; IUCN: Gland, Switzerland; WRI: Washington, DC, USA, 2014.

10. Jansen, M.; Guariguata, M.R.; Raneri, J.E.; Ickowitz, A.; Chiriboga-Arroyo, F.; Quaedvlieg, J.; Kettle, C.J. Food for Thought: The Underutilized Potential of Tropical Tree-Sourced Foods for 21st Century Sustainable Food Systems. People Nat. 2020, 2. [CrossRef] 
11. Padulosi, S.; Bala Ravi, S.; Rojas, W.; Valdivia, R.; Jager, M.; Polar, V.; Gotor, E.; Mal, B. Experiences and Lessons Learned in the Framework of a Global UN Effort in Support of Neglected and Underutilized Species. Acta Hortic. 2013, 517-532. [CrossRef]

12. Peters, C.M.; Gentry, A.H.; Mendelsohn, R.O. Valuation of an Amazonian Rainforest. Nature 1989, 339, 655-656. [CrossRef]

13. Bioversity New World Fruits Database. Available online: https://www.bioversityinternational.org/e-library/databases/newworld-fruits / (accessed on 9 November 2020).

14. Van Loon, R.; Lagneaux, E.; Wiederkehr Guerra, G.; Chiriboga-Arroyo, F.; Thomas, E.; Gamarra, B.; van Zonneveld, M.; Kettle, C. Barriers to adopting a diversity of NUS fruit trees in Latin American food systems. In Orphan Crops for Sustainable Food and Nutrition Security: Promoting Neglected and Underutilized Species; Routledge: London, UK, 2021.

15. Hunter, D.; Borelli, T.; Beltrame, D.M.O.; Oliveira, C.N.S.; Coradin, L.; Wasike, V.W.; Wasilwa, L.; Mwai, J.; Manjella, A.; Samarasinghe, G.W.L.; et al. The Potential of Neglected and Underutilized Species for Improving Diets and Nutrition. Planta 2019, 250, 709-729. [CrossRef]

16. Hergoualc'h, K.; Blanchart, E.; Skiba, U.; Hénault, C.; Harmand, J.-M. Changes in Carbon Stock and Greenhouse Gas Balance in a Coffee (Coffea Arabica) Monoculture versus an Agroforestry System with Inga Densiflora, in Costa Rica. Agric. Ecosyst. Environ. 2012, 148, 102-110. [CrossRef]

17. Somarriba, E.; Beer, J. Productivity of Theobroma Cacao Agroforestry Systems with Timber or Legume Service Shade Trees. Agrofor. Syst. 2011, 81, 109-121. [CrossRef]

18. Mansourian, S.; Vallauri, D. Restoring Forest Landscapes: Important Lessons Learnt. Environ. Manag. 2014, 53, 241-251. [CrossRef] [PubMed]

19. Leakey, R.R. Converting 'Trade-Offs' to 'Trade-Ons' for Greatly Enhanced Food Security in Africa: Multiple Environmental, Economic and Social Benefits from 'Socially Modified Crops'. Food Secur. 2018, 10, 505-524. [CrossRef]

20. Lojka, B.; Preininger, D.; Van Damme, P.; Rollo, A.; Banout, J. Use of the Amazonian Tree Species INGA Edulis for Soil Regeneration and Weed Control. J. Trop. For. Sci. 2012, 24, 89-101.

21. Montúfar, R.; Laffargue, A.; Pintaud, J.-C.; Hamon, S.; Avallone, S.; Dussert, S. Oenocarpus Bataua Mart. (Arecaceae): Rediscovering a Source of High Oleic Vegetable Oil from Amazonia. J. Am. Oil Chem. Soc. 2010, 87, 167-172. [CrossRef]

22. Martinelli, G.D.C.; Schlindwein, M.M.; Padovan, M.P.; Gimenes, R.M.T. Decreasing Uncertainties and Reversing Paradigms on the Economic Performance of Agroforestry Systems in Brazil. Land Use Policy 2019, 80, 274-286. [CrossRef]

23. Salazar-Díaz, R.; Tixier, P. Effect of Plant Diversity on Income Generated by Agroforestry Systems in Talamanca, Costa Rica. Agrof. Syst. 2019, 93, 571-580. [CrossRef]

24. Global Forest Watch Dashboard by Country and Region. Available online: https:/ /www.globalforestwatch.org/dashboards/ country/PER (accessed on 29 March 2021).

25. Finer, M.; Novoa, S.; Garcia, R. MAAP \#75: Pope to Visit Madre de Dios, Region with Deforestation Crisis (Peru). MAAP 2017. Available online: https:/ / maaproject.org/2017/mdd_pope/ (accessed on 16 April 2021).

26. Moore, T. Deforestation in Madre de Dios, its implications for first peoples. In Peru: Deforestation in Times of Climate Change; International Work Group for Indigenous Affairs (IWGIA): Copenhagen, Denmark, 2019; p. 201.

27. Nicolau, A.P.; Herndon, K.; Flores-Anderson, A.; Griffin, R. A Spatial Pattern Analysis of Forest Loss in the Madre de Dios Region, Peru. Environ. Res. Lett. 2019, 14, 124045. [CrossRef]

28. Robiglio, V.; Reyes, M.; Castro, E. Diagnóstico de los Productores Familiares en la Amazonía Peruana; ICRAF Oficina Regional para América Latina: Lima, Peru, 2015; p. 208.

29. Huertas Castillo, B.; García Altamirano, A. (Eds.) Los Pueblos Indígenas de Madre de Dios: Historia, Etnografía y Coyuntura; CRI: Peru, 2003; ISBN 978-87-90730-80-2.

30. Osorio Arrascue, B.E. Impacto de Los Sistemas Agroforestales en El Desarrollo Sostenible Del Ámbito de Influencia de La Vía Interoceánica Sur en El Distrito de Tambopata, Madre de Dios, Perú; Universidad Nacional Agraria La Molina, Escuela de Postgrado: Lima, Peru, 2011.

31. Minagri Madre de Dios: Minagri Invierte S/10 Millones en Proyectos de Reconversión Productiva. Available online: https: / /www.gob.pe/institucion/minagri/noticias/29160-madre-de-dios-minagri-invierte-s-10-millones-en-proyectos-dereconversion-productiva (accessed on 20 October 2020).

32. INEI. INEI Madre de Dios: Compendio Estadístico 2018; INEI: Lima, Peru, 2018.

33. Caballero Espejo, J.; Messinger, M.; Román-Dañobeytia, F.; Ascorra, C.; Fernandez, L.E.; Silman, M. Deforestation and Forest Degradation Due to Gold Mining in the Peruvian Amazon: A 34-Year Perspective. Remote Sens. 2018, 10, 1903. [CrossRef]

34. Garrish, V.; Perales, E.; Duchelle, A.E.; Cronkleton, P. The REDD Project in Brazil Nut Concessions in Madre de Dios, Peru. Available online: https:/ / www.cifor.org/knowledge/publication/5268/ (accessed on 4 August 2020).

35. Cardozo, E.G.; Muchavisoy, H.M.; Silva, H.R.; Zelarayán, M.L.C.; Leite, M.F.A.; Rousseau, G.X.; Gehring, C. Species Richness Increases Income in Agroforestry Systems of Eastern Amazonia. Agrof. Syst. 2015, 89, 901-916. [CrossRef]

36. Torres, A.B.; Marchant, R.; Lovett, J.C.; Smart, J.C.; Tipper, R. Analysis of the Carbon Sequestration Costs of Afforestation and Reforestation Agroforestry Practices and the Use of Cost Curves to Evaluate Their Potential for Implementation of Climate Change Mitigation. Ecol. Econ. 2010, 69, 469-477. [CrossRef]

37. Padulosi, S.; Thompson, J.; Rudebjer, P. Fighting Poverty, Hunger, and Malnutrition with Neglected and Underutilized Species: Needs, Challenges, and the Way Forward; Bioversity International: Rome, Italy, 2013.

38. Goodman, L.A. Snowball Sampling. Ann. Math. Stat. 1961, 32, 148-170. [CrossRef] 
39. Peña, J. Sistematización de Experiencias Del Proyecto "Fortaleciendo Medios de Vida Ante El Cambio Climático En Madre de Dios, Amazonia Peruana, 2016-2018; 2018.

40. R Studio Team. RStudio: Integrated Development Environment for R; RStudio Team: Boston, MA, USA, 2020.

41. R Core Team. A Language and Environment for Statistical Computing; Foundation for Statistical Computing: Vienna, Austria, 2020.

42. Canty, A.J. Resampling Methods in R: The Boot Package. Newsl. R Proj. Vol. 2002, 2, 3.

43. Williams, J.T. Global Research on Underutilized Crops: An Assessment of Current Activities and Proposals for Enhanced Cooperation; Bioversity International: Rome, Italy, 2002.

44. Leakey, R.R.B. From Ethnobotany to Mainstream Agriculture: Socially Modified Cinderella Species Capturing 'Trade-Ons' for 'Land Maxing'. Planta 2019, 250, 949-970. [CrossRef] [PubMed]

45. Smith, N.; Vasquez, R.; Wust, W. Cinderella Fruits and Cultural Forests in Pacaya-Samiria, Peruvian Amazon. Amaz. Rev. Antropol. 2010, 2, 328-350.

46. Van Looy, T.; Carrero, G.O.; Mathijs, E.; Tollens, E. Underutilized Agroforestry Food Products in Amazonas (Venezuela): A Market Chain Analysis. Agrofor. Syst. 2008, 74, 127-141. [CrossRef]

47. Denevan, W.M.; Padoch, C.; Prance, G.T.; Treacy, J.M.; Unruh, J.; Alcorn, J.B.; Paitán, S.F.; Inuma, J.C.; de Jong, W. Swidden-Fallow Agroforestry in the Peruvian Amazon; New York Botanical Garden Press: New York, NY, USA, 1988; Volume 5.

48. Chavez, A.B.; Perz, S.G. Adoption of Policy Incentives and Land Use: Lessons from Frontier Agriculture in Southeastern Peru. Hum. Ecol. 2012, 40, 525-539. [CrossRef]

49. Nygren, P.; Leblanc, H.A.; Lu, M.; Luciano, C.A.G. Distribution of Coarse and Fine Roots of Theobroma Cacao and Shade Tree Inga Edulis in a Cocoa Plantation. Ann. For. Sci. 2013, 70, 229-239. [CrossRef]

50. Akter, M.S.; Oh, S.; Eun, J.-B.; Ahmed, M. Nutritional Compositions and Health Promoting Phytochemicals of Camu-Camu (Myrciaria Dubia) Fruit: A Review. Food Res. Int. 2011, 5, 1728-1732. [CrossRef]

51. Degnon, R.G.; Adjou, E.S.; Noudogbessi, J.-P.; Metome, G.; Boko, F.; Dahouenon-Ahoussi, E.; Soumanou, M.; Sohounhloue, D.C. Investigation on Nutritional Potential of Soursop (Annona Muricata L.) from Benin for its Use as Food Supplement against Protein-Energy Deficiency. Int. J. Biosci. 2013, 3, 1-10.

52. Brouwer, R.; Chiriboga-Arroyo, F.; Jansen, M.; Ehrenberg, F.; Vargas, R.; Guariguata, M.R.; Kettle, C.; Bardales, R.; Corvera, R.; Garcia Roca, M.; et al. Establishment Success of Brazil Nut Trees in Smallholder Amazon Forest Restoration Depends on Site Conditions and Management. Under review.

53. Salman, D.; Summase, I.; Fudjaja, L.; Tiring, D.N. Productivity and income analysis of certified cacao farmers (UTZ certified) and non-certified cacao farmers. In Proceedings of the IOP Conference Series: Earth and Environmental Science, South Sulawesi, Indonesia, 30 March 2020; IOP Publishing: Bristol, UK, 2021; Volume 681, p. 012049.

54. Mukul, A.Z.A.; Rahman, M.A. Production and Profitability of Banana in Bangladesh-an Economic Analysis. Int. J. Econ. Financ. Manag. Sci. 2013, 1, 159-165.

55. Bongers, G.; Jassogne, L.; Ibrahim, W.; Nibasumba, A.; Mukasa, D.; Van Asten, P.J.A. Understanding and exploring the evolution of coffee-banana farming systems in Uganda. In Proceedings of the Tenth European IFSA Symposiums, Aarhus, Denmark, 1-4 July 2012.

56. Bosshard, E.; Jansen, M.; Löfqvist, S.; Kettle, C.J. Rooting Forest Landscape Restoration in Consumer Markets-A Review of Existing Marketing-Based Funding Initiatives. Front. For. Glob. Chang. 2021, 3, 148. [CrossRef]

57. Recanati, F.; Guariso, G. An Optimization Model for the Planning of Agroecosystems: Trading off Socio-Economic Feasibility and Biodiversity. Ecol. Eng. 2018, 117, 194-204. [CrossRef]

58. Kirkby, C.A.; Giudice-Granados, R.; Day, B.; Turner, K.; Velarde-Andrade, L.M.; Dueñas-Dueñas, A.; Lara-Rivas, J.C.; Yu, D.W. The Market Triumph of Ecotourism: An Economic Investigation of the Private and Social Benefits of Competing Land Uses in the Peruvian Amazon. PLoS ONE 2010, 5, e13015. [CrossRef]

59. Rahman, S.A.; De Groot, W.T.; Snelder, D.J. Exploring the agroforestry adoption gap: Financial and socioeconomics of litchi-based agroforestry by smallholders in Rajshahi (Bangladesh). In Smallholder Tree Growing for Rural Development and Environmental Services; Springer: Berlin, Germany, 2008; pp. 227-243.

60. Wainaina, P.; Minang, P.A.; Gituku, E.; Duguma, L. Cost-Benefit Analysis of Landscape Restoration: A Stocktake. Land 2020, 9 , 465. [CrossRef]

61. DRAMDD. Información Agrícola—DRAMDD; DRAMDD: Puerto Maldonado, Peru, 2021.

62. Jack, B.K. Market Inefficiencies and the Adoption of Agricultural Technologies in Developing Countries; Center for Effective Global Action (CEGA): Berkley, CA, USA, 2013.

63. Wossen, T.; Berger, T.; Di Falco, S. Social Capital, Risk Preference and Adoption of Improved Farm Land Management Practices in Ethiopia. Agric. Econ. 2015, 46, 81-97. [CrossRef]

64. Chitakira, M.; Torquebiau, E. Barriers and Coping Mechanisms Relating to Agroforestry Adoption by Smallholder Farmers in Zimbabwe. J. Agric. Educ. Ext. 2010, 16, 147-160. [CrossRef]

65. De Sousa, K.; van Zonneveld, M.; Holmgren, M.; Kindt, R.; Ordoñez, J.C. The Future of Coffee and Cocoa Agroforestry in a Warmer Mesoamerica. Sci. Rep. 2019, 9, 1-9. [CrossRef]

66. Caceres, D.M. Agrobiodiversity and Technology in Resource-Poor Farms. Interciencia 2006, 31, $403-410$.

67. De Urzedo, D.I.; Piña-Rodrigues, F.C.M.; Feltran-Barbieri, R.; Junqueira, R.G.P.; Fisher, R. Seed Networks for Upscaling Forest Landscape Restoration: Is it Possible to Expand Native Plant Sources in Brazil? Forests 2020, 11, 259. [CrossRef] 
68. Yamada, M.; Gholz, H.L. An Evaluation of Agroforestry Systems as a Rural Development Option for the Brazilian Amazon. Agrofor. Syst. 2002, 55, 81-87. [CrossRef]

69. Lagneaux, E.; Andreotti, F.; Neher, C. Cacao, Copoazu and Macambo: Exploring Theobroma Diversity in Smallholder Agroforestry Systems of the Peruvian Amazon. Agrofor. Syst. 2021, 1-10. [CrossRef]

70. Froese, R.; Pinzón, C.; Schönenberg, R.; Schilling, J. Local actions against global dynamics COVID-19 as a catalyst of social transformation in the South-Western Amazon? In Peace and the Pandemic International Perspectives on Social Polarization and Cohesion in Times of COVID-19; Universität Koblenz-Landau: Landau, Germany, 2021.

71. Duguma, L.A.; van Noordwijk, M.; Minang, P.A.; Muthee, K. COVID-19 Pandemic and Agroecosystem Resilience: Early Insights for Building Better Futures. Sustainability 2021, 13, 1278. [CrossRef] 